Ковальчук Галина Олександрівна

доктор педагогічних наук, доцент, професор кафедри педагогіки та психології

ДВНЗ «Київський національний економічний університет імені Вадима Гетьмана», м. Київ, Україна

ORCID ID 0000-0002-8328-1471

Gallina_Kovalchuk@ukr.net

\title{
РЕАЛІЗАЦІЯ ДІЯЛЬНІСНОГО, ОСОБИСТІСНО ТА ПРОФЕСІЙНО ОРІЄНТОВАНИХ ПІДХОДІВ У ВИКЛАДАННІ СОЦІАЛЬНО-ЕКОНОМІЧНИХ ДИСЦИПЛІН 3 ВИКОРИСТАННЯМ ІНФОРМАЦЙНО-КОМУНІКАЦЙНИХ ТЕХНОЛОГІЙ
}

\begin{abstract}
Анотація. Стаття присвячена актуальній проблемі інтегрованого застосування традиційних (предметоцентричних) та інноваційних (студентоцентричних) технологій навчання, зокрема ІКТ, для реалізації діяльнісного, особистісно- та професійно- орієнтованих підходів у процесі вивчення соціально-економічних дисциплін. Показана роль інструментів хмароорієнтованих сервісів Google для формування професійних компетентностей і розвитку медійно-інформаційної грамотності студентів - майбутніх фахівців економістів за допомогою IКТ. Обгрунтовано сутність поняття «Робочий навчальний простір дисципліни». Наведено приклади змістової і функціональної структури електронного середовища 3 «Методики викладання економіки». Висвітлено моделі навчальних дій студента для самоорганізації навчання та самопроектування навчальних результатів у контексті концепції студентоцентризму.
\end{abstract}

Ключові слова: електронне навчання; електронний навчальний простір; мультиагентне навчання; самопроектування; цифрова компетентність; хмарні сервіси.

\section{1. ВСТУП}

Постановка проблеми. Посилення вимог до професійної підготовки фахівців для економіки і бізнесу, організації навчання в сучасній освіті зумовлюють зростання значення особистісно- та професійно- оріснтованих технологій навчання на різних етапах системи неперервної економічної освіти. 3 кожним наступним етапом економічної освіти (початкова, середня, професійна не вища, вища професійна, післядипломна, освіта для людей «третього віку») роль викладача зменшується. Відповідно, перед викладачем постають завдання - забезпечення умов для сприяння студентами у самопроектуванні й формуванні їх власних професійно-значимих компетентностей, реалізації індивідуалізованих цінностей навчання з використанням дидактичних ресурсів електронного середовища, у тому числі - хмарних сервісів. При цьому необхідно в процесі професійної підготовки студентів у ВНЗ представляти можливості для самостійного застосування потужних ресурсів інформаційнокомунікаційних технологій (IКТ) щодо особистісно-професійного розвитку.

Зростаючий потік інформації, стислі строки та потреби збільшення ефективності засвоєння матеріалу шляхом активізації навчання є основними чинниками необхідності використання IКТ в освіті. В умовах, коли обсяг навчальних матеріалів постійно зростає, а кількість аудиторних годин на їх вивчення зменшується, безперечною необхідністю $є$ використання інформаційно-комунікаційних веб-орієнтованих технологій. Серед основних цілей цього процесу $є$ збільшення участі й посилення відповідальності, у першу чергу, студента за результати власної навчальної праці, через проектування структури i змісту його навчально-пізнавальної діяльності, 
відтворюваності позитивних наслідків, запланованої ефективності й об'єктивно діагностованих кінцевих результатів навчання.

У зв’язку зі зростанням обсягів навчальної інформації, збільшенням частки самостійної роботи в структурі бюджету навчального часу і скороченням аудиторної роботи для вивчення змісту дисципліни постають серйозні проблеми, які повинен розв'язувати безпосередньо викладач у ході навчального процесу, зокрема такі: забезпечення доступності, повноти й динамічності дидактичних матеріалів; оперативного і своєчасного зворотного зв'язку зі студентами за результатами їхнього виконання завдань; створення умов для загальної оглядовості, відкритості завдань і робіт, для взаємонавчання і самонавчання. Розв'язанню цих проблем значною мірою сприятиме використання хмаро-орієнтованих сервісів та інтерактивних електронних освітніх ресурсів для розвитку медійно-інформаційної грамотності і цифрової компетентності майбутнього фахівця XXI століття.

Аналіз останніх досліджень і публікацій. Аналіз наукової літератури показує, що категорія «ІКТ» в освіті має усталене тлумачення, що не викликає суперечностей. Цей термін включає в себе всі технології, що використовуються для конвергенції комп'ютерних, аудіовізуальних, телефонних мереж та інформаційних систем з метою роботи з інформацією і спілкування. Застосування IКТ у навчально-виховному процесі змінює традиційні форми організації пізнання і взаємодії суб'єктів навчання в умовах сучасного інформаційного суспільства, забезпечують передумови для відкритої освіти, мультимодального і мультиагентного навчання.

Щодо проблеми нашого дослідження засадничими $є$ концептуальні й науковометодологічні публікації і розробки з питань інформатизації в освіті й розвитку відкритої освіти, мобільного і змішаного навчання; формування інформаційної грамотності і цифрової компетентності, розроблення дистанційних курсів і проектування електронного навчального середовища, застосування хмарних сервісів для навчання, розвитку самокерованого навчання й самопроектування студентів, реалізації різних науково-методологічних підходів у процесі професійної підготовки майбутніх фахівців.

Загальні питання інформатизації суспільства окреслено у Національній програмі інформатизації суспільства [1]. Водночас, протягом чотирьох років (2010-2014 рр.) Інститутом ЮНЕСКО 3 інформаційних технологій в освіті опубліковано 28 аналітичних записок щодо різноманітних аспектів використання IКТ в освіті, для підвищення ефективності у практиці цього процесу [2].

Розвитку теорії інформатизації в освіті присвячені праці багатьох учених [3], зокрема Бикова В., Жалдака М., Запорожченко Ю., Козлакової Г., Литвинової С., Логвінова І., Ляудіса В., Сергієнка В., Спіріна О., Тяглова В., Тіхомірова О., Торубари О. та ін. Концептуальні положення про соціальний, професійний характер Інтернет-комунікації висвітлені у працях Барнеса С., Войкунського А., Ковальчук Г., Халяпіної Л., та ін.; теорії та методики використання ІКТ у процесі професійної підготовки досліджували Дмитрієв О., Подопригоров Л., Полат Є., Франчук В. та ін.

Актуальним й перспективним напрямком розвитку сучасних IКТ в освіті $\epsilon$ розвиток мобільного і змішаного навчання в електронному просторі з використанням відкритих освітніх ресурсів. Наразі «відкриті освітні ресурси» - це матеріали, які використовуються у сфері освіти, які знаходяться у вільному доступі й можуть бути багатократно використані, змінені або надані третім особам [4, с. 24]. Означені аспекти проблеми широко досліджуються в рамках міжнародних проектів і програм (зокрема Інституту ЮНЕСКО з інформаційних технологій в освіті (iite.unesco): «Доступ, рівні права і якість: перспективи розвитку системи вищої освіти в епоху цифрових технологій», «Відкриті рішення»), були предметом обговорення у рамках симпозіумів і 
конгресів багатьох міжнародних організацій (ЮНЕСКО, EDUCAUSE, Міжнародної конференції з освіти дорослих (КОНФІНТЕА), Міжнародної ради з дистанційної освіти (ICDE), Міжнародної федерації з обробки інформації (IFIP), New Media Consortium, Сколтех), провідних університетів Австралії, Бразилії, Китаю, Кореї, США, Південної Африки, ОАЕ та ін.) [4], [5], [6]. Метою цих проектів є виявлення чинників, як технологічні зміни у зв'язку з розвитком соціально-економічного контексту впливають на зміну освітніх потреб і можливостей, і які їх основні наслідки для окремих осіб, урядів, компаній і громадянського суспільства. У Декларації принципів інформаційного суспільства (2003) виражено прагнення «побудувати зорієнтоване на інтереси людей, відкрите для всіх і спрямоване на розвиток інформаційне суспільство, в якому кожен міг би створювати інформацію і знання, мати до них доступ, користуватися й обмінюватися ними» [4]. Такий підхід відповідає стратегіям ЮНЕСКО щодо формування інклюзивних спільнот знань, розвитку можливостей місцевих спільнот для розширення доступу до інформації і знань, їх збереження, сприяння інформаційному обміну в усіх сферах діяльності. В основі спільнот знань повинні лежати чотири основних принципи: свобода вираження думки, всезагальний доступ до інформації та знань, повага до культурної та мовної різноманітності, якісна освіта для всіх.

Різні аспекти формування інформаційної грамотності та иүифрової компетентності висвітлено у публікаціях аналітиків ЮНЕСКО [5], працях Б. Андерсена, Г. Ковальчук, Г. Онкович, Ю. Тельнова, Л. Тимчук, С. Толісано [8]-[14]. Для досягнення успіху в постійно змінюваних умовах та ефективного вирішення проблем у всіх сферах життєдіяльності, окремі особи, спільноти і країни повинні володіти низкою життєво важливих умінь і навичок, у тому числі умінням знайти інформацію і критично ії оцінювати, здатністю створювати нову інформацію і знання. Інформаційна грамотність відкриває для людей нові можливості і сприяє підвищенню якості життя. Попри це, вона тісно пов'язана з іншими видами грамотності, зокрема медійною і цифровою, компетентністю в галузі ІКТ. Сильвія Розенталь Толісано (S. R. Tolisano) - фахівець навчання 3 формування навичок для XXI століття, автор посібника «Технології цифрового наративу для освітян», значну увагу приділяє класифікації видів і складових цифрової компетентності та медіа- й інформаційної грамотності, які є складовими соціальної компетентності особи [8]. Інформаційна та медіа грамотність - знання, уміння, мотивація та відповідальність, пов'язані з пошуком, розумінням, організацією, архівуванням цифрової інформації та іiї критичним осмисленням, а також із створенням матеріалів з використанням цифрових ресурсів текстових, зображувальних, аудіо та відео (Г. Солдатова, О. Рассказова) [9, с. 157].

Характеризуючи особливості сучасної медіаосвіти у використанні інтегрованого простору знань, Г. Онкович [9, с. 171-175] підкреслює, що «найбільш революційною особливістю нових комунікаційних технологій $€$ ïх інтерактивний характер, a основними відмінними рисами «нових медіа»є децентралізація, висока пропускна здатність, інтерактивність, гнучкість форми, змісту та використання інформації». Знання, накопичувані та збережувані у віртуальному освітньому середовищі, постійно доповнюються й оновлюються, є інтегрованими, доступними й затребуваними, що забезпечується створенням і використанням інтегрованого простору знань (IПЗ). На думку Ю. Тельнова, функціонування цього простору (ІПЗ) реалізується медіа-освітніми технологіями, що дозволяє об'єднати різноманітні джерела інформації за різними дисциплінами, спеціальностями та учасниками освітнього процесу в рамках єдиної системи; забезпечити постійни розвиток системи за рахунок оновлення знань та досвіду, набутих у процесі навчання; надати релевантну навчальним завданням інформацію кожному суб' єкту навчання з урахуванням його знань і потреб [10]. 
Як вказує Л. Тимчук, еволюція цифрових технологій, комп'ютерних мереж, використання сучасних технологій в освіті має відігравати ключову роль у створенні необхідних умов для саморозвитку всіх суб'єктів навчальної діяльності, активізації когнітивних і творчих процесів, формування необхідних компетентностей, сприяти утвердженню гуманістичних ідей [11]. Глобальне поширення світових інформаційнокомунікаційних мереж вимагає іншого змісту і якості освіти, легітимізує швидку зміну традиційних навчальних моделей на інтегративні, динамічні, що поєднують гуманістичний i технологічний підходи, уможливлюють розкриття пізнавального й творчого потенціалу майбутніх фахівців, формування компетентностей XXI століття: когнітивних, креативних, комунікативних та технологічних [11]; [12], [13].

Питанням проектування електронного навчального середовища і розроблення дистанційних курсів присвячені праці багатьох учених, серед яких В. Биков, В. Кремень, В. Кухаренко, В. Сергієнко, О. Спірін, В. Франчук, А. Стрюк та ін. [13][16]. Як зазначають В. Биков, В. Кремень, відкрите навчальне середовище - частина глобального освітнього простору, що не включає саму людину, суттєвий оточуючий освітній простір конкретної людини, елементи і зв'язки якого існують природно i/aбо створені штучно і які безпосередньо i/або опосередковано впливають, а їх властивості свідомо i/або підсвідомо використовуються людиною впродовж життя для забезпечення формального, неформального та інформального навчання [14]. Учені наголошують: «Створити навчальне середовище - це означає побудувати таке об'єктне оточен ня учня (суттєвий оточуючий простір), в якому враховані (визначені на етапі його про- ектування) і реалізовані основні суттєві аспекти навчального-виховного процесу, який повинен здійснюватись в цьому НС, а також передбачена можливість адекватного роз- витку цього середовища щодо динаміки розвитку цілей і обмежень його створення та ефективного і безпечного використання. Створити для розвитку творчої особистості найбільш сприятливі умови (тобто побудувати для неї ефективне, педагогічно виважене НС) - означає зробити «практично все» для особистісного розвитку учня i «практично все» для отримання максимально можливих результатів будь-якої його діяльності, що ініціюється зовні» [14, с. 10].

Три рівні інтерактивності суб'єктів електронного навчання характеризують Бент Б. Андерсен, Катя ван ден Бринк [15]. До таких відносять рівень реактивної взаємодії, рівень активної взаємодії та рівень двосторонньої взаємодії суб'єкта і навчального середовища, моделювання реальних об'єктів і процесів, управління елементами віртуального навчального середовища. Важливим завданням викладача $є$ проектування дидактичних умов і завдань для реалізації всіх трьох названих рівнів інтерактивності студента і навчального середовища.

Особиве значення в електронному освітньому просторі мають хмарні сервіси. Окремі аспекти використання хмарних технологій в освітньому процесі висвітлено у працях багатьох вітчизняних науковців, зокрема: В. Бикова, Т. Вакалюк, Л. Довгаль, В. Кухаренка, С. Литвинової, А. Стрюка, та ін. [16]-[22].

Основні дефініції й рекомендації щодо використання хмарних сервісів викладено у спеціальній публікації Національного Інституту стандартів і технологій [17].

Сутнісні переваги роботи у хмарному середовищі підкреслює С. Литвинова: «Значна економія коштів на придбання програмного забезпечення; доступність до ресурсів незалежно від місця знаходження, операційної системи, видів комп'ютерної техніки; збільшення можливостей для організації спільної роботи і різноманітної комунікації; зменшення проблем зберігання і резервного копіювання даних виводить середню освіту на новий рівень розвитку». Водночас зазначає, що «з широким розповсюдженням і розвитком хмарних технологій виникає проблема педагогічного проектування навчальних середовищ, створення різних моделей, для оптимального 
використання їх можливостей у забезпеченні навчальної мобільності всіх учасників навчально-виховного процесу» [18, с. 56].

Місце і значення хмаро орієнтованих засобів навчання в інформаційному середовищі ВНЗ обгрунтовує А. Стрюк [19].

Щодо створення хмарно орієнтованого навчального середовища (ХОНС), на думку Т. Вакалюк, його метою $є$ досягнення певних дидактичних цілей, виконання завдань, об'єднання суб'єктів навчання для ефективної співпраці, орієнтованої на підвищення якості навчальних результатів засобами хмарних сервісів. «Компоненти ХОНС мають гнучку структуру i функціонал, адаптуються до особливостей конкретного змісту середовища, потреб і здібностей як учнів, так і вчителів. Фактично вчитель може проектувати навчальне середовище під певний логічно завершений фрагмент навчання та з урахуванням пізнавальних можливостей, здібностей, інтересів і рівня попередньої навчальної підготовки конкретного учня» [20].

Детально переваги і недоліки навчання в електронному освітньому просторі характеризують В. Алєксєєв, Л. Довгаль, Ю. Свсикова, О. Свсєєв, О. Савкін, А. Яковлєва-Чернишова [21]; [22]. Зокрема, до переваг електронного освітнього простору відносять такі: можливість асинхронної передачі інформації для забезпечення гнучкості процесу навчання; індивідуалізацію навчання, яка підвищує якість подання інформації та збільшення швидкості передавання інформації; зниження, як правило, вартості навчання, що веде до більшої доступності знань і демократизації освітньої практики; максимальний рівень взаємодії для індивідів, які відчувають себе більш впевнено при спілкуванні в режимі онлайн, ніж при безпосередньому навчанні в аудиторії; можливість практикувати електронне навчання як ізольовано самостійного виду навчання, так і як доповнення до традиційного навчання - у вигляді інтегрованої системи; можливість онлайн моніторингу навчального процесу.

Поряд 3 цим, електронне освітнє середовище повинно бути орієнтоване на розвиток раціональної свідомості і гуманістичних якостей особистості, але i продуктивного, соціально схвалюваної поведінки суб'єкта як у сфері професійних відносин, так і у сфері міжособистісної взаємодії [22]. Це передбачає необхідність формування у студентів ефективних поведінкових, комунікативних i емоційних патернів психічної активності особистості, що становлять менталітет сучасної людини. 3 цією метою використовуються принципово нові технології Е-навчання, що забезпечують ефект «соціального навчання». Наразі розподілене навчання реалізується за допомогою соціальних інтеракцій, опосередкованих комп'ютерною комунікацією, яка передбачає спільну участь суб' єктів у соціальній практиці, що трансформує освітнє середовище за рамки тимчасових і локальних обмежень і презентує концепцію «знання як результат колаборації в «спільнотах практики». У таких технологіях реалізовані метафори «розподіленого інтелекту», «суспільства обміну знаннями», «соціального навчання». Таке розподілене освітне середовище характеризується відкритим інформаційно-комунікативним простором, опосередковане новим дизайном через опору на мультимедійні засоби навчання й гіпермедіа, що дозволяє оптимізувати забезпечення професійної і соціальної компетентності студентів, і спрямоване на формування у них механізмів самонавчання і самовиховання [22].

До недоліків електронного освітнього простору відносять: необхідність забезпечення доступу до комп'ютерних систем і систем зв'язку для входження в електронний освітній простір; висока вартість електронного навчання хорошої якості, оскільки розробка веб-курсів вимагає великих тимчасових i фінансових витрат; достатня цифрова компетентність суб'єктів навчання; поширення на практиці «цифрової нерівності», існування суттєвих відмінностей між суб'єктами навчання у технічних можливостях гаджетів і доступу в Інтернет. 
Попри це, створення умов «все під рукою» сприяє змінам як в організації навчального процесу, так і в методах навчання. З'являються нові вимоги до підбору дидактичних завдань (інтерактивність, он-лайн реалізація, гейміфікація), прискорення процесу впровадження різних електронних освітніх ресурсів (ЕОР) [20].

Динамічне упровадження IKT для навчання забезпечує вирішення багатьох проблем особистісно-орієнтованого навчання: диференціації та індивідуального розвитку, гуманізації, формування індивідуальної освітньої перспективи учнів. Особистісно-орієнтована освіта реалізується через гуманітарні технології відкритого типу, що втілюють фундаментальні філософські, психологічні, педагогічні ідеї про людину i процеси іiі індивідуально-особистісного розвитку, про освіту як людиноформуючий, самоорганізовуваний, смислопороджуючий процес, про виховання як педагогічну підтримку особистості й індивідуальності, про освітній простір як проекцію життєвого світу суб'єктів навчання [22]; [23]. Структура змісту сучасної особистісно-орієнтованої освіти включає такі компоненти: аксіологічний, когнітивний, діяльнісно-творчий, особистісний. Їх реалізація передбачає застосування різноманітних загальних методологічних i конкретних науково-практичних підходів, зокрема діяльнісного, особистісно та професійно-орієнтованого навчання [23].

Ааналіз результатів вищеназваних досліджень та публікацій щодо застосування IКT в освіті й професійному навчанні, зокрема, свідчить про всеохоплюючий i глобальний характер цього процесу. Однак дотепер недостатньо досліджень, у яких моделюється система інтеграції форм і методів традиційного й електронного навчання, формування самостійності студента для роботи в електронному освітньому просторі, забезпечення зв' язку між формальним і неформальним навчання.

Мета статті. Пропонуємо власний досвід Е-навчання дисципліни «Методика викладання економіки» для студентів спеціальності «Економіка та підприємництво». Висвітлення специфіки використання ІКТ щодо організації навчального середовища і взаємодії суб' єктів Е-навчання для реалізації діяльнісного, особистісно- та професійно орієнтованих підходів у професійному навчанні становить мету цієї статті.

\section{2. МЕТОДИКА ДОСЛІДЖЕННЯ}

Дослідження здійснювалось у процесі викладання психолого-педагогічних i соціально-економічних дисциплін («Психологія діяльності та навчальний менеджмент», «Методика викладання економіки», «Управління знаннями») для студентів-майбутніх економістів Київського національного економічного університету імені Вадима Гетьмана та університету економіки і права «КРОК». У процесі дослідження використано низку методів, що відповідають цілям роботи: аналіз теоретичних і методичних першоджерел щодо проблем реалізації багаторівневої системи методологічних підходів у процесі професійної підготовки студентів майбутніх економістів, проектування й застосування електронного навчального середовища, використання електронних сервісів і хмарних технологій для навчання економічних дисциплін у ВНЗ, педагогічне спостереження, систематизація навчальних результатів і продуктів навчальної діяльності студентів; узагальнення власного досвіду дистанційного навчання соціально-економічних дисциплін. 


\section{3. РЕЗУЛЬТАТИ ДОСЛІДЖЕННЯ}

\section{1. Огляд навчальної дисципліни «Методика викладання економіки» в системі соціально-економічних дисицплін}

Головною парадигмою економічної освіти $\epsilon$ розуміння того, що розвиток економічної сфери суспільства значною мірою зумовлений характером життєдіяльності людини, iї світоглядом, соціально відповідальною поведінкою. Економічна освіта охоплює чотири блоки дисциплін, які формують сучасний світогляд і зумовлюють потребу в постійному оновленні соціально-економічних знань, умінь, навичок: загальноосвітній, фундаментальний, інновачійно-практичний і блок дисциплін спеціальної підготовки. Дисципліни, що входять до названих блоків, забезпечують багатоаспектне вивчення закономірностей економічної сфери суспільства на різних рівнях складності. Вирізняють такі групи економічних дисциплін: 1) загальноекономічні (економікс, основи економіки, економіка суб'єктів господарювання); 2) соціально-економічні (економічна психологія, дидактика економіки, психологія бізнесу, економічна соціологія, економічна історія, соціальна педагогіка, професійна освіта, економічна педагогіка, методика викладання економіки); 3) професійноекономічні (фахового спрямування); 4) природничо-математичні економічного спрямування; 5) інженерно-комп’ютерні економічного спрямування.

У розвитку сучасної економічної освіти переважає традиційна система директивної ЗУН-дидактики, студент залишається об'єктом педагогічного впливу, а викладачі (у міру своєї зацікавленості) реалізують різноманітні технології, методи й прийоми активізації навчання 3 метою збільшення обсягу засвоєння студентами економічних знань. Водночас, переважна більшість студентів мають особистісно обумовлені дидактичні цілі й уявлення щодо навчання економічних дисциплін, а його результати пов'язують 3 отриманням переваг у своєму професійному й життєвому розвитку. У зв'язку з цим зроблено припущення, що ефективність навчання пов'язана із самовизначенням, самопроектуванням і саморозвитком студентів засобами технологій професійно-, компетентнісно- й особистісно-орієнтованого навчання.

Дисципліна «Методика викладання економіки» («MBE»), у процесі вивчення якої розглядаються зміст, форми $\mathrm{i}$ методи навчання 3 економічних дисциплін, $\epsilon$ завершальною в циклі психолого-педагогічної підготовки бакалавра 3 економіки в економічному університеті для здобуття кваліфікації «Викладач економіки». При цьому передбачається узагальнення i систематизація знань 3 дисциплін психологопедагогічного циклу, моделювання фрагментів навчального процесу, диверсифікація даної системи знань у сфері професійної (економічної) та навчальної діяльності. В основі такого підходу - розуміння фундаментальності, інваріантності психологопедагогічних знань щодо всіх видів діяльності. Понятійно-термінологічний апарат дисципліни враховує принцип наступності у навчанні й включає звичні для економістів поняття 3 економічної науки, які поступово доповнюються поняттями 3 психології та дидактики.

Оскільки економіка - наука багатогалузева і багатопрофільна, то розробка змісту програми «Методика викладання економіки» 3 врахуванням конкретних економічних дисциплін (макроекономіка, мікроекономіка, банківська справа, страхова справа, податкова система тощо) $\epsilon$ досить складною проблемою. Попри це, важко спрогнозувати освітньо-вікові особливості контингенту потенціальних учнів майбутнього викладача економічних дисциплін, тому у розробці й вивченні предмета «Методика викладання економіки» було використано технології навчального проектування й евристично-контекстного навчання, що забезпечують передумови для 
реалізації діяльнісного, особи стіно- та професійно-оріієнтованих підходів у підготовці майбутніх фахівців. Це дозволило інтегрувати знання з інших психолого-педагогічних дисциплін до конкретних умов навчальної діяльності та формувати у студентів практичні навички та вміння. У процесі вивчення дисципліни «Методика викладання економіки» студенти вчаться розробляти й реалізовувати навчальний технологічний проект засвоєння змісту певної економічної дисципліни для відповідної освітньовікової навчальної групи. Опанувавши курс МBE, майбутні викладачі мають навчитися обгрунтовано обирати й застосовувати у навчальному процесі 3 економіки сучасні технології навчання, методи та засоби їх реалізації, спрямованні на формування i розвиток творчої, ініціативної особистості, здатної приймати ефективні рішення та гармонічно облаштовувати стосунки 3 природою та соціумом. Під час навчання «MBE» потрібно створити умови для формування особистісно-фахової позиції майбутнього викладача економіки, опанування студентами основних закономірностей процесу навчання, його цілей методичних вимог до організації. 3 цією метою передбачено систему завдань для дослідницької діяльності. Основний акцент зроблено на самостійній роботі студентів, розвитку навичок і потреб самостійної діяльності та реалізацію отриманих знань на практиці.

У процесі навчання дисципліни «МВЕ» використовуються форми і методи традиційного й електронного навчання з використанням IКТ. Загальна інформація про дисципліну розміщена на сторінці MOODLE (рис. 1).
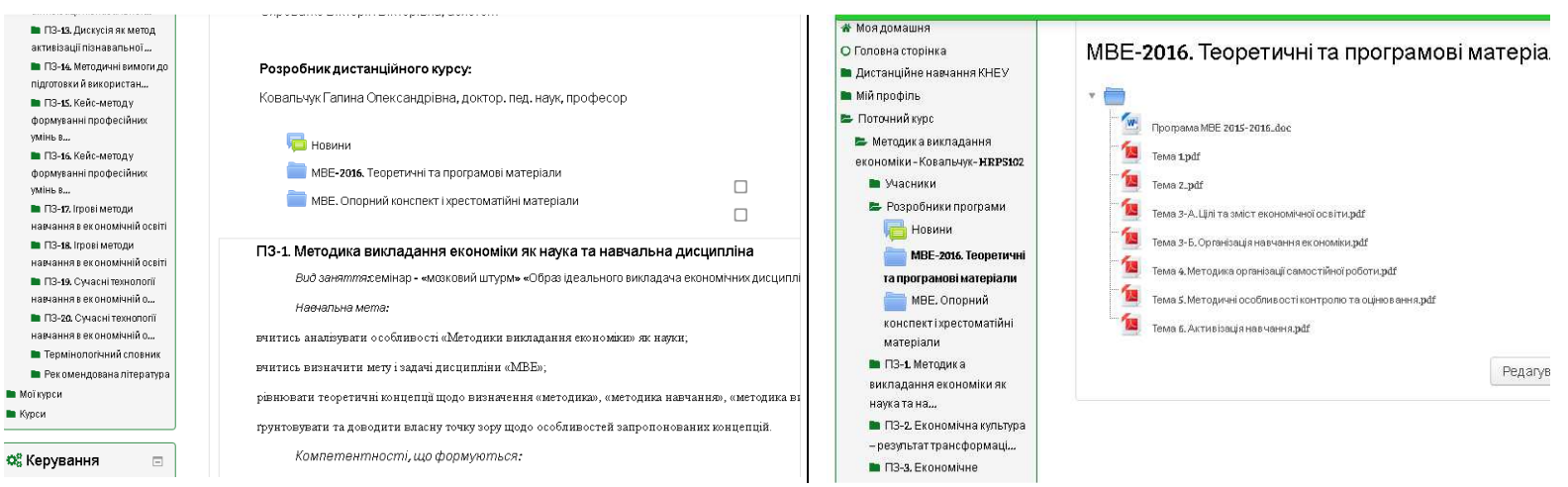

Рис. 1. Загальна інформація про дисичиліну «MBE» на сторінияі MOODLE

Серед факторів, які негативно впливають на успішність і якість вивчення дисципліни «МВЕ» в економічному університеті, виділимо такі: недостатність інформаційно-методичного забезпечення викладання економічних дисциплін та методики викладання економіки; недостатність матеріально-технічної бази для проведення занять 3 «МВЕ», що спричинює обмеженість використання ефективних технологій викладання, що базуються на використанні сучасних IКT; недоліки класичної традиційної системи організації навчального процесу, якій притаманний стереотип, що викладач повинен дати готові знання; велика кількість учасників груп, що утруднює використання індивідуального підходу в процесі навчання та застосування активних методів навчання; недостатня розвиненість самостійності як якості особистості студента; амбівалентна професійна спрямованість студентів; прояви блокування аффіліації у багатьох, що викликає почуття відчуженості та $є$ проблемою в організації спільної навчальної діяльності.

Для подолання таких несприятливих тенденцій упроваджуються різноманітні інноваційні дидактичні технології, зокрема змішаного й електронного навчання. У процесі вивчення дисципліни «Методика викладання економіки» експериментальними факторами для підвищення ефективності, забезпечення доступності й мобільності 
навчання нами було визначено такі: форми, методи й прийоми взаємодії та роботи викладача і студентів з навчальним матеріалом; використання проектно-технологічного підходу, активізаційних та інтерактивних методів навчання засобами IКТ, зокрема хмарних сервісів. Хмарні технології в навчальному процесі $\epsilon$ ефективними для самостійної роботи студентів у дистанційному навчанні й для колективних навчальних досліджень, де першочергового значення набуває можливість постійного контакту студентів між собою і з викладачем задля забезпечення своєчасного моніторингу якості роботи.

\section{2. Професійно-оріснтований електронний «Робочий навчальний простір» дисципліни «Методика викладання економіки»}

Проведення професійно-орієнтованих навчальних занять вимагає забезпечення певних умов навчання з використанням відповідних ресурсів, які поділяються на кілька основних груп: IКТ, засоби навчання, у тому числі й інформаційно-методичне забезпечення процесу, приміщення та обладнання для проведення навчальних занять.

3 урахуванням сучасних вимог до професійної підготовки, у процесі викладання соціально-економічних дисциплін для студентів - майбутніх економістів використовуємо найрізноманітніші дидактичні матеріали і засоби навчання, які ми класифікуємо на такі види: описи предметів і явищ за допомогою символів (вербальні посібники (підручники, довідники, робочі зошити, текстові таблиці); графічні схематичні посібники (схеми різних видів і призначення); графічні статистичні посібники); натуральні об'єкти (предмети господарської діяльності людей, що вивчаються в аудиторії; господарські об'єкти в їхньому природному середовищі, які вивчаються під час екскурсій чи виробничої практики); відтворення натуральних об'єктів і явищ (моделі (зокрема комп'ютерні); ілюстративні зображення); цифрові наративи різних форм (документальні, художні, короткометражні, анімаційні фільми, мікрофільми, радіопрограми, рекламні відеоролики, відеофрагменти, презентації, фотослайди, електронні тексти, розповіді в блогах, відеокліпи, відеоблоги, фотоколажі, описи подій в соцмережах, твітер-романи тощо). Дедалі більшого поширення та інтересу набуває використання цифрових наративів у процесі навчання. Як вказує Л. І. Тимчук «Digital narrative» - спосіб передавання раціонально-логічної та почуттєво-емоційної складових інформаційного повідомлення за допомогою цифрових технологій, що дає можливість розширити ряд смислів і відтінків у ході інтерпретації власної точки зору на подію, про яку розповідається. Створення цифрових наративів відбувається на перетині гносеологічних та емоційних аспектів навчання; поєднує практику рефлексивної розповіді й теорію, інтелект і афект [11].

Для розширення можливостей застосування різноманітних ресурсів IКТ з метою підвищення ефективності навчання й забезпечення спільного «предметного поля» 3 «МВЕ» нами було створено локальний E-nортфель дисципліни, який розміщено в ресурсах локальної мережі університету - в комп'ютерному центрі $(К Ц)$ на комп'ютері викладача розміщено папку з дидактичними матеріалами, до якої мали доступ студенти через інші робочі станції. У цій же локації студенти створювали свої робочі папки 3 виконаними завданнями. Узагальнений вигляд сторінки локального Е-портфеля 3 дисципліни «Методика викладання економіки» («МВЕ») показано на рис. 2. 


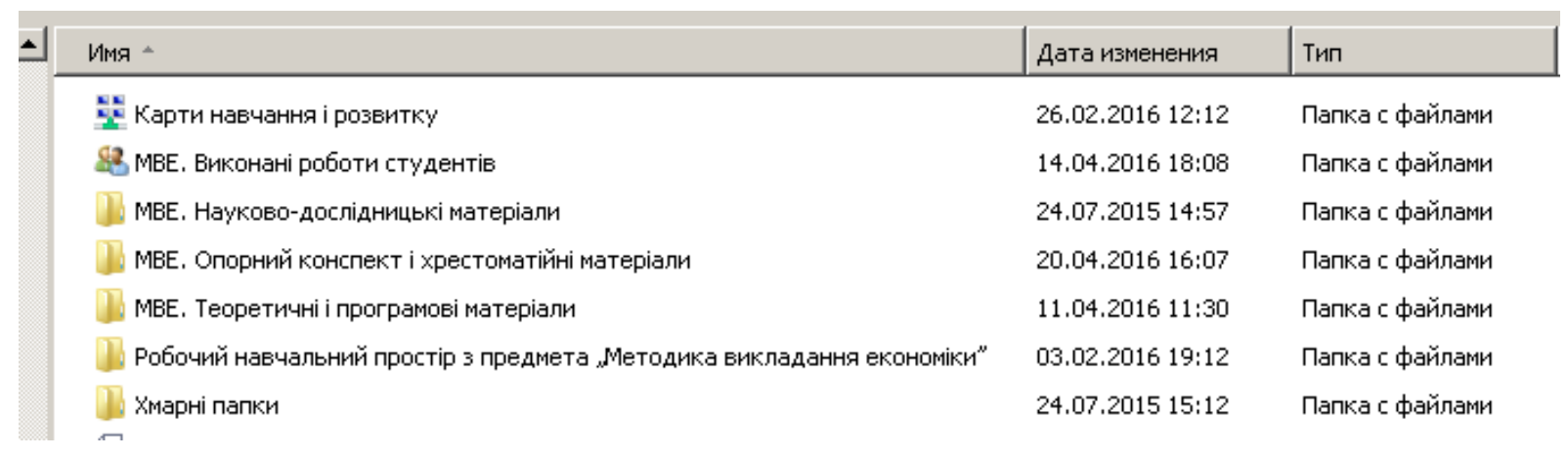

Рис. 2. Локальний Е-портфель з дисиипліни «МВЕ» (для студентів 2-3-х курсів фінансово-економічного факультету КНЕУ)

У структурі Е-портфеля представлено такий вміст робочих папок для навчання:

Теоретичні $i$ програмові матеріали: матеріали лекцій, робоча навчальна програма, методичні рекомендації для вивчення дисципліни, структура завдань та їх оцінювання, картка СРС, картка самооцінювання, тематичний план лекційних занять, календарний план практичних занять, перелік завдань для самоконтролю, тести для самоконтролю, теми для самостійних робіт, перелік рекомендованої літератури.

Нормативно-правові акти: документи, законодавство. реферати.

Виконані роботи студентів: виконані завдання, презентації, проекти, есе,

Карти навчання і розвитку: проекти, портфоліо, робочий зошит, фотографії тощо.

Опорний конспект і хрестоматійні матеріали: презентації лекцій і практичних занять, опорний конспект за темами програми, електронні навчальні посібники тощо.

Науково-дослідницькі матеріали: анкети для опитування, тести самоперевірки, матеріали наукових публікацій.

Хмарні папки: спільна пошта (викладач уточнює завдання, дає настанови, консультації, перевіряє роботи, реалізує спільний зі студентом «захист-контроль»).

У процесі роботи з таким портфелем виявились проблеми, які відбирали багато навчального часу і створювали додаткові труднощі для навчання. Зокрема:

1) працювати можна було тільки в комп'ютерному центрі, з урахуванням режиму роботи та розкладу занять інших груп;

2) якість навчальної роботи значною мірою залежала від якості комп'ютерів локальної мережі та їх програмного забезпечення;

3) якщо студенти копіювали дидактичні матеріали на свої гаджети, через деякий час інформаційне наповнення ставало застарілим;

4) для представлення своїх виконаних завдань студентам необхідно в позаурочний час завантажувати свої матеріали у спільну папку в КЦ;

5) до навчальних матеріалів мали доступ усі, хто міг знаходитися в КЦ;

6) у разі будь-якої технічної несправності в КЦ спільна робота через локальну мережу зупинялась.

Для розв'язання зазначених проблем нами було розроблено електронний комплект дидактичних матеріалів електронний «Робочий навчальний простір дисципліни» $(E-P H \Pi)$ і розміщено для використання за допомогою сервісів Google Диску, Classroom, Moodle. «Робочий навчальний простір дисципліни» $є$ змістове Eполе навчальної дисиипліни, компоненти якого забезпечують: набуття суб'єктами предметних знань, формування нормативних знань, умінь і навичок, формування професійних компетентностей, цифрової та мультимедійної грамотності, розширення доступу до відкритих освітніх ресурсів та інструментів мобільного навчання. 
Загальний вигляд структури «Робочого навчального простору» показано на рис. 3. Функціональні можливості Е-РНП на платформі Google Диск:

- використовувати розміщені викладачем е-версії навчальних теоретичних матеріалів: тексти і презентації лекцій, зміст дисципліни за темами, календарні плани занять для кожної групи, зміст практичних занять, завдання до кожної теми; хрестоматійних матеріалів: е-версії книг відомих авторів, наукові та публіцистичні статті за тематикою навчання тощо; кейсів, ситуаційних матеріалів: сайти, описи, відео сюжети, фото, мультимедіа тощо);

- створювати свої дидактичні матеріали - у «Цифровому портфелі студента»: розміщувати свої виконані завдання у форматі doc., у додатках Google (наприклад Glogster), виконувати спільні проекти груп у режимі on-line (бізнес-плани, презентації, квести тощо), знайомитися 3 роботами інших студентів. Важлива перевага для студентів - доступ до матеріалів у будь-який час, з будь-якого місця і будь-якого гаджета. Якість доступу залежить тільки від якості послуг оператора зв'язку. Приклад «Цифрового портфеля студента» представлено на рис. 4;

- для викладача (який $є$ адміністратором сторінки) є можливість здійснювати моніторинг активності студента (коли і які матеріали створює, додає, або вилучає); випереджальну перевірку робіт (напередодні заняття) відповідно до термінів за тематичним календарним планом. Це створює додаткові умови для обговорення виконаних студентом робіт на занятті;

- спільна робота викладача і студентів з вивчення предмета може здійснюватися в будь-якому місці в аудиторний чи позааудиторний час. Виконані роботи студентів зберігаються у їхніх «Цифрових портфелях». У разі, якщо відбулось недобросовісне запозичення самостійної роботи, викладач наголошує на цьому студентам, які представили однакові роботи.

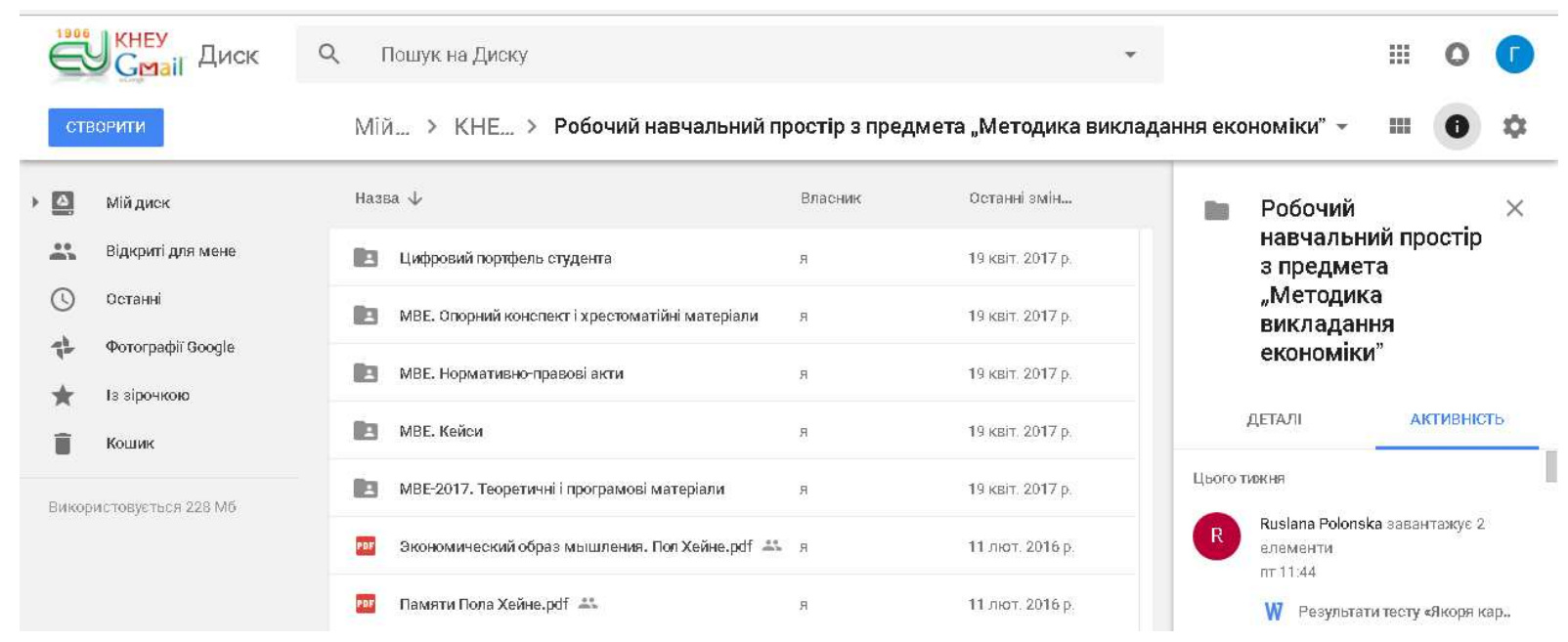

Рис. 3. Загальний вигляд структури «Робочого навчального простору з «МВЕ»

Підвищення ефективності роботи студентів 3 навчальними матеріалами в Е-РНП можемо довести показниками збільшення активності студентів порівняно з їх роботою в локальному Е-портфелі дисципліни. Так свої «робочі папки» в локальній мережі КЦ створювали не більше 25-30\%\% учасників навчальних груп. Кількість виконуваних завдань на заняття 3 часом зменшувалась (від 4-5 до 0-1). $У$ «хмарному» просторі створили свої Е-«Цифрові портфелі» понад 80\% студентів. Кількість виконуваних завдань в «хорошистів» була сталою протягом усього часу навчання (2-3 на заняття), у невстигаючих студентів, які пізніше включаються в роботу - 3 часом збільшувалась (4- 
5 на заняття). На завершення вивчення дисципліни студенти, які відкладають роботу на «потім», інтенсивно працюють. Чимало учасників навчальних груп цікавляться, чи можна буде й надалі працювати 3 Е-РНП. Моніторинг показує, що близько 5\% студентів попередніх років навчання запитують доступ до Е-РНП дисципліни.

Викладач створює архів виконаних робіт студентів різних років навчання та різних видів завдань. Його адміністрування залежить тільки від самого викладача. Попри це, викладач надає дозвіл на доступ до матеріалів та операції з ними залежно від своєї дидактичної стратегії: «тільки перегляд», перегляд і редагування, внесення змін. У локальній мережі такої можливості немає. Тут функціонування архіву залежить від адміністратора КЦ. Практика показує, що в Е-РНП для папок 3 теоретичними i хрестоматійними матеріалами, кейсами і документами достатньо доступу тільки для перегляду. Адже деякі студенти, які мають недостатню цифрову компетентність можуть випадково вилучити або змінити матеріали викладача. Щодо своїх «Цифрових портфелів» студенти розпоряджаються на свій розсуд, створюють внутрішні папки, до яких мають доступ окремі особи. При цьому викладач як адміністратор має змогу моніторити всю активність студента, спостерігає, хто і з якого гаджета виконує $\mathrm{i}$ розміщує завдання.

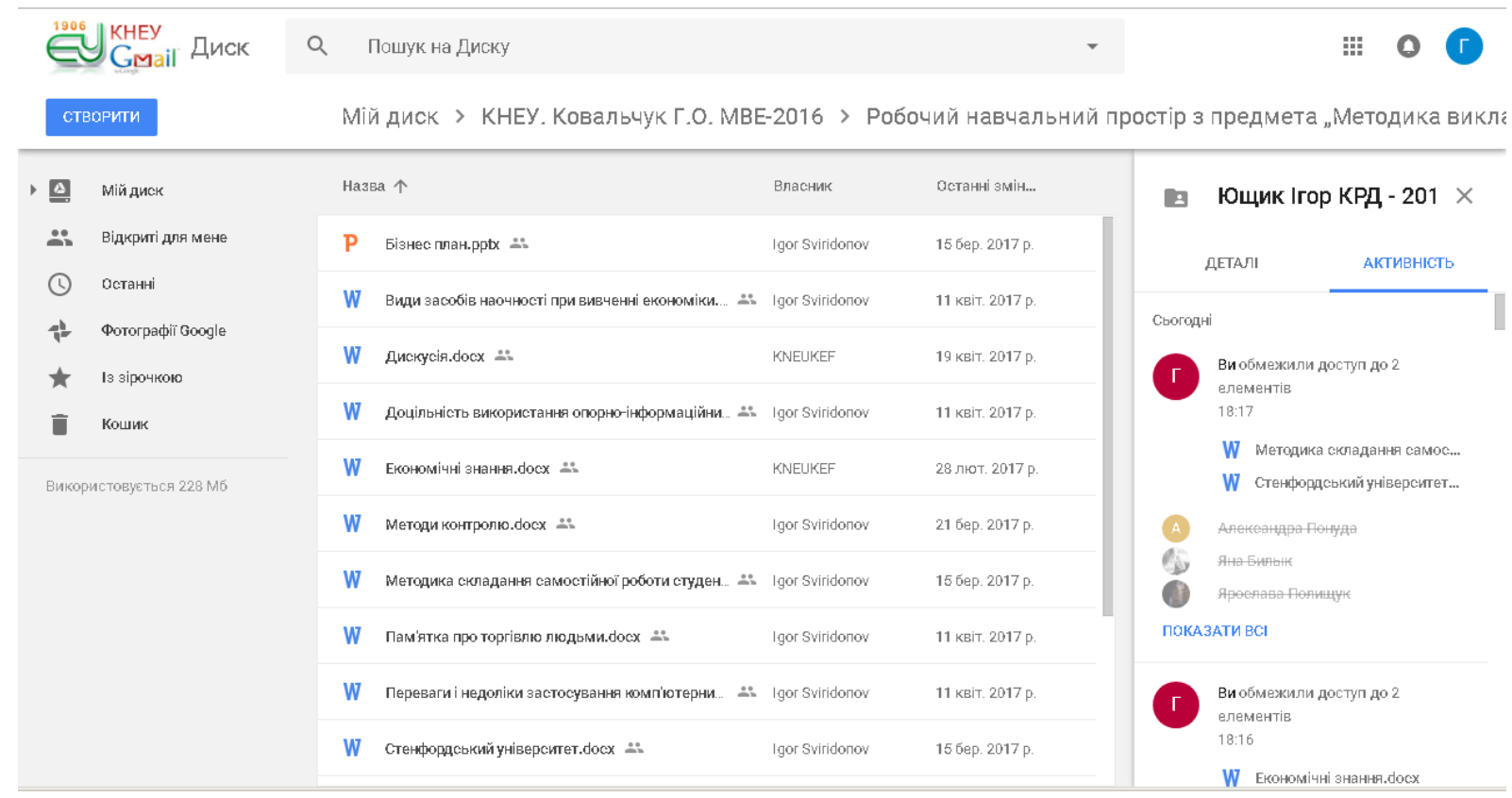

Рис. 4. Загальний вигляд «Цифрового портфеля студента»з виконаними завданнями

Створений е-портал самостійних робіт студентів забезпечує передумови для використання сервісів антиплагіату - перевірки робіт на запозичення. На розсуд викладача можуть бути перевірені поточні завдання, обов'язково перевіряються курсові роботи. Протокол перевірки на антиплагіат долучається як додаток до самої роботи та розміщується в Е-«Цифровому портфелі».

Розроблення й використання Е-«РНП»надає можливості студентам для створення своєрідної «спільноти знань». Завдання, які виконують і розміщують студенти в «цифровому портфелі» демонструють своєрідну дидактичну історію (наратив) самого студента - які аспекти змісту і види робіт для нього більш цікаві й важливі.

Так студенти набувають навичок взаємодії у системі управління знаннями, з якою доведеться безпосередньо зустрітися у професійній діяльності. Мета управління знаннями полягає в тому, щоб допомогти людям краще працювати спільно, 
використовуючи зростаючі обсяги інформації та керуючи ними. До етапів процесу управління знаннями в кожній організаційній структурі відносять такі: створення навчального середовища; навчання правильного використання інформації; навчання роботи із системою управління знаннями; навчання принципам роботи організації; навчання спільного використання знань; навчання у клієнтів (взаємонавчання). Результатом успішної системи управління знаннями має стати організація, що володіє знаннями, здатна до самонавчання та саморозвитку. Ключовим принципом в управлінні знаннями є доставка потрібних знань в потрібний час зацікавленим людям у рамках робочих груп та організації в цілому. Адже оптимальне використання інформації в процесі діяльності є необхідною умовою ії продуктивності й ефективності. Для цього потрібні відповідні технології орієнтації працівників на продуктивний пошук і використання відповідних інформаційних матеріалів. Обіг знань у рамках одної організації набувають форми створення бази знань, які забезпечують накопичення й можливості їх повторного використання. Для розвитку організаційних (корпоративних) знань суттєвим $\epsilon$ виявлення всіх можливих джерел знань та забезпечення доступу до них за допомогою різних систем управління знаннями.

Для забезпечення ефективної взаємодії суб'єктів ринку знань та вирішення багатьох з означених завдань, на нашу думку, доцільним є запровадження системи кластерної освіти 3 характеристиками мультиагентного і мультимодального навчання. Мультиагентне навчання в даному випадку означає використання у межах однієї дидактичної системи різноманітних ресурсів для навчання та здобуття профільної спеціалізації у певній галузі знань чи виробництва. Навчальними агентами можуть виступати усі джерела і суб'єкти, які володіють інформацією і знаннями, доцільними для досягнення навчальних цілей. Мультимодальність означає концептуальний підхід до організації навчання, за якого учасники навчальних груп в одному навчальному курсі використовують різні форми і методи навчання (денне, вечірнє, дистанційне навчання, I-навчання, web-навчання, самонавчання, взаємонавчання тощо).

\section{4. ВИСНОВКИ ТА ПЕРСПЕКТИВИ ПОДАЛЬШИХ ДОСЛІДЖЕНЬ}

Інформаційно-комунікаційні технології навчання $\epsilon$ важливим інструментом забезпечення якості навчання майбутніх фахівців для економіки й підприємництва, формування їхніх професійних компетентностей і професійно значущих особистісних якостей, які є компонентом гуманітарних засад розвитку спільнот, що навчаються, $\mathrm{i}$ забезпечення якості життя на рівні локального соціально-економічного середовища. Головним чинником ефективності реалізації технологій навчання виступає суб'єктна активність учнів/студентів у форматі самокерованого навчання.

Упровадження описаних дистанційних курсів та електронних дидактичних сервісів у професійну підготовку майбутніх фахівців-економістів демонструє модель змішаного навчання, яке забезпечує інтеграцію в застосуванні традиційних (предметоцентричних) та інноваційних (студентоцентричних) технологій навчання, зокрема IКТ, для реалізації діяльнісного, особистісно- та професійно-орієнтованих підходів у процесі вивчення соціально-економічних дисциплін.

При цьому, діяльнісний підхід у навчанні за допомогою Е-РНП реалізується через збільшення активності й інтерактивності студентів, використання різноманітних сервісів для виконання завдань та їх відображення у «цифровому портфелі студента».

Особистісно-орієнтований підхід полягає у тому, що студент у процесі енавчання має можливість реалізувати свої індивідуальні особливості, здатність до 
вибору, рефлексії, саморегуляції становленні суб'єктних властивостей (автономності, самостійності, діалогічності, відповідальності, відкритості тощо) [23].

Професійно-орієнтований підхід реалізується у розвитку навичок використання цифрового середовища з професійно-значимою метою, при цьому формується медійноінформаційна грамотність, яка полягає в інтеграції ресурсів електронного простору для вирішення навчально-професійних завдань.

Щодо розвитку цифрової компетентності - студенти вчаться представляти свою роботу в цифровому просторі - це включає i назву роботи, i форматування, i структурування змісту, і впорядкування структурних елементів.

На основі даного дослідження можемо стверджувати, що збагачення навчальної діяльності та взаємодії суб'єктів навчального процесу (викладачів, студентів, ринку праці тощо), удосконалення роботи 3 навчальними матеріалами та виконання дидактичних завдань засобами IКТ і «хмарного» простору актуалізує дидактичні можливості веб-ресурсів, активізує участь студента в освоєнні змісту освіти.

Важливим і цікавим напрямком подальших досліджень $є$ створення можливостей для синхронізації робочих папок у відкритому е-просторі, створення прозорих папок «вітрин», із відображенням їх вмісту не відкриваючи кожну окремо.

Для розвитку професійно-значимої цифрової компетентності майбутніх фахівців економістів, на нашу думку, доцільно в процесі навчання у ВНЗ ознайомлювати з IКТ, СУЗ, програними продуктами i технологіями доступу до інформації, управління контентом, спільної роботи груп і соціально-орієнтованої взаємодії, потрібно залучати студентів до використання ресурсів корпоративного управління знаннями. 3 цією метою необхідна співпраця представників основних постачальників інтегрованих рішень та розробників програмних засобів управління знаннями.

Використання ресурсів електронного освітнього простору як своєрідної системи управління професійними знаннями дозволяє об'єднати можливості й зусилля багатьох суб'єктів неперервної освіти, за їх інтересами і потребами освітнього (економікопедагогічного) середовища. Функції портального сервера в цьому процесі може взяти на себе мультиінституційний суб'єкт - локальний координаційний центр освітніх ресурсів на базі певного навчального закладу, який діє на принципах державноприватного партнерства.

Наступними напрямками подальших досліджень у даній сфері $є$ розробки механізмів економіко-правової взаємодії в електронному просторі суб'єктів неперервної освіти, які реалізують освітні функції і $є$ бенефіціарами результатів навчання протягом усього життя.

\section{СПИСОК ВИКОРИСТАНИХ ДЖЕРЕЛ}

[1] Закон України "Про Національну програму інформатизації" від 04.02.1998, № 74/98-ВР. [Електронний ресурс]. URL: http://zakon3.rada.gov.ua/laws/show/74/98.

[2] "Технологии в высшем образовании: особенности ландшафта" [Электронный pecypc]. URL: http://ru.unesco.org/ИИТО ЮНЕСКО _ Электронная библиотека _ Технологии в высшем образовании _ особенности ландшафта.html) (дата обращения 18.07.2017) (in English)

[3] Международная конференция Образование $u$ виртуальность [Электронный pecypc]. URL: www.setlab.net (дата обращения 13.08.2017).

[4] Рекомендации по работе с открытыми образовательными ресурсами (ООР) в сфере высшего образования (2011) Институт ЮНЕСКО по информационным технологиям в образовании, Содружество обучения. Москва. с. 24, 2011.

[5] Рекомендации ЮНЕСКО по политике в области мобильного обучения (UNESCO Policy Guidelines for Mobile Learning (2013). Институт ЮНЕСКО по информационным технологиям в образовании (ИИТО ЮНЕСКО), Москва, с. 44, 2015. 
[6] Open Educational Quality Initiative (2009). URL: http://www.oer-quality.org (vieved on 18.07.2017)

[7] Педагогічні аспекти відкритого дистаниійного навчання: монографія, за ред. О. О. Андрєєва, В. М. Кухаренка. Харків: ХНАДУ, с. 212, 2013.

[8] "Curriculum21: Mapping the Global Classroom of the Future" [Electronic resource]. URL: www.curriculum21.com/author/silvia-rosental-tolisano/ (vieved on 30.07.2017)

[9] Медийно-информационная грамотность в России: дорога в будущее. Сборник материалов Всероссийской научно-практической конференции Медиа- и информационная грамотность $в$ информационном обществе (Москва, 24-27 апреля 2013 г.). Сост. Е. И. Кузьмин, И. В. Жилавская, Д. Д. Игнатова, под ред. И. В. Жилавской. М.: МЦБС, с. 232, 2014.

[10] Ю. Ф. Тельнов, Реализация компетентностного похода к обучению на основе управления знаниями. Москва: Научная сессия МИФИ, 2007.

[11] Л. І. Тимчук, "Теоретико-методичні засади проектування цифрових наративів у навчанні майбутніх магістрів освіти": автореф. дис. ... докт. пед.наук, спец. 13.00.10 - інформаційнокомунікаційні технології в освіті. ІІТЗН НАПН України, Київ, с. 41, 2017.

[12] Г. О. Ковальчук, 'Internet - навчання студентів 3 економічних дисциплін: можливості для професійної адаптації"». Проблеми освіти: зб. наук. праџь, Київ: Інститут інноваційних технологій і змісту освіти МОН України, Вип. 63, ч. 1, с. 120-125, 2010.

[13] Технологї̈ розробки дистаниійного курсу: навчальний посібник [В. Ю. Биков, В. М. Кухаренко, Н. Г. Сиротенко, О. В. Рибалко, Ю. М. Богачков], за ред. В. Ю. Бикова та В. М. Кухаренка. Київ: Міленіум, с. 324, 2008.

[14] В. Ю. Биков, В. Г. Кремень, "Категорії простір і середовище: особливості модельного подання та освітнього застосування". Теорія і практика управління соціальними системами: філософія, психологія, педагогіка, соиіологія, № 3, с. 3-16, 2013.

[15] Бент Б. Андерсен, Катя ван ден Бринк, "Три уровня интерактивности мультимедийной разработки. Мультимедиа в образовании". Москва, 2007. [Электронный ресурс]. URL: http://didaktor.ru/triurovnya-interaktivnosti-multimedijnoj-razrabotki/ (дата обращения 20.07.2017)

[16] Л. К. Раицкая, Дидактические и психологические основы применения технологий Веб 2.0. в высшем профессиональном образовании: монография. - Москва: МГОУ, с. 173, 2011.

[17] The NIST Definition of Cloud Computing. Recommendations of the National Institute of Standards and Technology: NIST Special Publikation (September 2011) [Electronic resource]. URL: http://csrc.nist.gov/publications/nistpubs/800-145/SP800-145.pdf (vieved on 18.07.2017)

[18] Моделювання й інтеграція сервісів хмаро орієнтованого навчального середовища: монографія. [Н. Копняк, Г. Корицька, С. Литвинова, Ю. Носенко, С. Пойда, В. Сєдой, О. Сіпачова, І. Сокол, О. Спірін, І. Стромило, М. Шишкіна], за заг. ред. С. Г. Литвинової. Київ: ЦП «Компринт», с. 163, 2015.

[19] А. М. Стрюк, "Система хмаро орієнтованих засобів навчання як елемент інформаційного освітньонаукового середовища ВНЗ". Інформаційні технології $і$ засоби навчання, № 4 (42), с. 150158, 2014.

[20] Т. А. Вакалюк, "Структурно-функціональна модель хмаро-орієнтованого навчального середовища для підготовки бакалаврів інформатики". Інформаційні технології $і$ засоби навчання, Том 59, № 3, с. $51-61,2017$.

[21] А. И. Евсеев, А. Н. Савкин, Ю. В. Евсикова, Разработка электронных образовательных ресурсов. Психолого-дидактические вопросы познавательной (учебной) деятельности: методическое пособие. Москва: МЭИ, с. 116, 2009.

[22] Л. С. Довгаль, А. Ю. Яковлева-Чернышева, В. П. Алексеев, "Внутривузовское электронное пространство как основа новых образовательных технологий университета". Концепт: Научнометодический электронный журнал. № 12 (декабрь), ART 14337, 2014. [Электронный ресурс]. URL: http://e-kon-cept.ru/2014/14337.htm (дата обращения 19.07.2017)

[23] Г. О. Ковальчук, Технологї навчання економічних дисииллін в системі неперервної освіти (теоретико-методичний аспект): монографія. Київ: КНЕУ, с. 511, 2014. 


\title{
РЕАЛИЗАЦИЯ ДЕЯТЕЛЬНОСТНОГО, ЛИЧНОСТНО И ПРОФЕССИОНАЛЬНО-ОРИЕНТИРОВАННОГО ПОДХОДОВ В ПРЕПОДАВАНИИ СОЦИАЛЬНО-ЭКОНОМИЧЕСКИХ ДИСЦИПЛИН С ИСПОЛЬЗОВАНИЕМ ИКТ
}

\author{
Ковальчук Галина Александровна \\ доктор педагогических наук, доцент, профессор кафедры педагогики и психологии \\ Киевский национальный экономический университет имени Вадима Гетьмана, г. Киев, Украина \\ ORCID ID 0000-0002-8328-1471 \\ Gallina_Kovalchuk@ukr.net
}

\begin{abstract}
Аннотация. Статья посвящена актуальной проблеме интегрированного применения традиционных (предметно-ориентированных) и инновационных (студентоцентричних) технологий обучения, в том числе ИКТ, для реализации деятельностного, личностно и профессионально ориентированных подходов в процессе изучения социальноэкономических дисциплин. Показана роль инструментов облако-ориентированных сервисов Google в формировании профессиональных компетенций и развитии медийноинформационной грамотности студентов - будущих экономистов с помощью ИКТ для обучения. Обосновано сущность понятия «Рабочее учебное пространство дисциплины». Приведены примеры содержательной и функциональной структуры электронной среды для дисциплины «Методики преподавания экономики». Описаны модели учебных действий студента для самоорганизации обучения и самопроектирования учебных результатов в контексте концепции студентоцентризма.
\end{abstract}

Ключевые слова: электронное обучение; электронное учебное пространство; мультиагентные обучения; самопроектирования; цифровая компетентность; облачные сервисы.

\section{REALIZATION OF ACTIVE, PERSONAL AND PROFESSIONALLY-ORIENTED APPROACHES BY ICT SUPPORT}

\author{
Halyna A. Kovalchuk \\ Doctor of Pedagogical Sciences, Associate Professor, Professor Pedagogic and Psyhology Department \\ Kyiv National Economic University named after Vadym Hetman, Kiev, Ukraine \\ ORCID ID 0000-0002-8328-1471 \\ Gallina_Kovalchuk@ukr.net
}

\begin{abstract}
The article is devoted to the problem of the integrated of traditional (content-centric) and innovative (student-centered) learning technologies, in particular ICT, for implementation of activity, personality and professional-oriented approaches in the studying socio-economic disciplines. Investigated the role of Google's cloud-oriented services tools in the development of professional competencies and the development of media-information literacy of students with the ICT for education. The essence of the notion "Working educational space of discipline" is substantiated. Examples of the content and functional structure of the electronic environment from "Methods of teaching economics" are given. The models of educational actions of the student for self-organization of training and self-designing of educational results in the context of the concept of student center-centered are outlined.
\end{abstract}

Keywords: E-learning; E-learning space; Multi-agent training; Self-design; Digital competence; Cloud services.

\section{REFERENCES (TRANSLATED AND TRANSLITERATED)}

[1] Law of Ukraine "On the National Program of Informatization" from 04.02.1998 № 74/98-BP. [online]. URL: http://zakon3.rada.gov.ua/laws/show/74/98 (in Ukrainian)

[2] Technologies in higher educaTion: Mapping The Terrain. [online]. URL: http:// http://iite.unesco.org/pics/publications/en/files/3214737.pdf

[3] International conference "Education and virtuality" (VIRT). [online]. URL: www.setlab.net (in Ukrainian) 
[4] Guidelines for Open Educational Resources (OEP) in Higher Education (2011) UNESCO Institute for Information Technology in Education, Commonwealth of Education. Moscow. p. 24, 2011. (in Russian)

[5] UNESCO Policy Guidelines for Mobile Learning (2013). UNESCO Institute for Information Technology in Education, Moscow, p. 44, 2015. (in Russian)

[6] Open Educational Quality Initiative (2009). [online]. URL: http://www.oer-quality.org

[7] Pedagogical aspects of open distance learning: monograph, Ed. O. O. Andreev and V. M. Kukharenko. Kharkiv: KNADI, p. 212, 2013. (in Ukrainian)

[8] Curriculum21: Mapping the Global Classroom of the Future. [online]. URL: www.curriculum21.com/author/silvia-rosental-tolisano/

[9] A. V. Onkovich, "Use of the integrated knowledge space in the educational process by means of media education". Zhurnalistyka, filolohiia ta mediaosvita: zbirnyk naukovykh dopovidei. T.2, p. 252-255. Poltava: Osvita, 2009. (in Ukrainian)

[9] Media-information literacy in Russia: the road to the future. Sbornik materialov Vserossijskoj nauchnoprakticheskoj konferencii "Media and information literacy in the information society" (Moscow, Apr. 2427, 2013). Compilers: E. I. Kuz'min, I. V. Zhilavskaja, D. D. Ignatova, Ed. I. V. Zhilavskaja. Moscow: The Intergovernmental Council of the UNESCO Program "Information for all" (IFA), Interregional Library Center cooperation, c. 232, 2014. (in Russian)

[10] Ju. F. Tel'nov, "Implementing a competency-based approach to learning based on knowledge management". Moscow: Nauchnaja sessija MIFI, 2007. (in Russian)

[11] L. I. Tymchuk, Theoretical and methodical principles of designing digital narratives in the training of future masters of education: avtoref. dys. ... dokt. ped.nauk, spets. 13.00.10 - Information and communication technologies in education. IIT3Н NAPS України, Київ, с. 41, 2017. (in Ukrainian)

[12] Г. О. Kovalchuk, "Internet - training students in economic disciplines: opportunities for professional adaptation". Problemy osvity: zb. nauk. prats, Kyiv,: Edition. 63, part. 1, p. 120 - 125, 2010. (in Ukrainian)

[13] Bent B. Andersen, Katja van den Brink, Three levels of interactive multimedia development. Multimedia in education. Moscow, 2007. [online]. URL: http://didaktor.ru/tri-urovnya-interaktivnosti-multimedijnojrazrabotki/ (in Russian)

[14] Technology for the development of a distance course: a tutorial. [V. Yu. Bykov, V. M. Kukharenko, N. H. Syrotenko, O. V. Rybalko, Yu. M. Bohachkov], Ed. V. Ju. Bykov and V. M. Kukharenko. Kyiv,: Milenium, p. 324, 2008. (in Ukrainian)

[15] V. Ju. Bykov, V. G. Kremen', "Categories 'space' and 'environment': the characteristics of the model representation and educational use", Teorija i praktyka upravlinnja social'nymy systemamy: philosophy, psychology, education, sociology, №3, p. 3-16, 2013. (in Ukrainian)

[16] L. K. Raickaja, Didactic and psychological fundamentals of Web 2.0 technologies. In higher professional education: a monograph. - Moscow: MSOU, c. 173, 2011. (in Russian)

[17] The NIST Definition of Cloud Computing. Recommendations of the National Institute of Standards and Technology: NIST Special Publikation (September 2011) - [online]. URL: http://csrc.nist.gov/publications/nistpubs/800-145/SP800-145.pdf

[18] Modeling and integration of cloud-based learning environment services: monograph.. [N. Kopniak et al.], Ed.. S. G. Lytvynova. Kyiv, TsP Komprynt, p. 163, 2015. (in Ukrainian)

[19] A. M. Striuk, "System of cloud-oriented training facilities as a part of information, educational and scientific university environment". Informatsiini tekhnolohii $i$ zasoby navchannia, № 4 (42), p. 150-158, 2014. (in Ukrainian)/

[20] T. A. Vakaliuk, "Structural and functional model of cloud oriented learning environment for bachelors of informatics training". Informatsiini tekhnolohii $i$ zasoby navchannia, T.59, № 3, p. 51-61, 2017. (in Ukrainian)

[21] A. I. Evseev, A. N. Savkin, Ju. V. Evsikova, Working-outof electronic educational resources. Psychological-didactic questions of cognitive (educational) activity: methodical manual. Moscow: MEI, p. 116, 2009. (in Russian)

[22] Г. O. Kovalchuk, Technologies of teaching economic disciplines in the system of continuous education (theoretical and methodical aspect): monograph. Kyiv,: KNEU, p. 511, 2014. (in Ukrainian)

[23] L. S. Dovgal', A. Ju. Jakovleva-Chernysheva, V. P. Alekseev, "Internship electronic space as the basis of the new educational technologies of the university". Koncept: Nauchno-metodicheskij jelektronnyj zhurnal. № 12 (Dec.), 2014. [online]. URL: http://e-kon-cept.ru/2014/14337.htm (in Russian)

\section{(cc) BY-NC-SA}

This work is licensed under Creative Commons Attribution-NonCommercial-ShareAlike 4.0 International License. 